\title{
PRIVATE OPERATION WITH PUBLIC SUPERVISION: EVIDENCE OF HYBRID MODES OF GOVERNANCE IN PRISONS*
}

\author{
Sandro Cabral \\ Federal University of Bahia (NPGA-UFBA) \\ Av. Reitor Miguel Calmon s/n, 3. andar \\ Salvador, Bahia, Brazil, 41110-903 \\ Phone: 55-71-3263 7302; Fax: 55-71-3263 7211 \\ E-mail: scabral@ufba.br \\ Sergio G. Lazzarini \\ Ibmec São Paulo \\ R. Quatá 300 \\ São Paulo, SP, Brazil 04546-042 \\ Phone: 55-11-4504-2387; Fax: 55-11-4504-2350 \\ E-Mail: SergioGL1@isp.edu.br
Paulo F. Azevedo
FGV-EESP \\ Rua Itapeva, 474 \\ São Paulo, SP, Brazil 01332-000 \\ Phone: 55-11-3281-3375; Fax: 55-11-3281-3357 \\ E-mail: paulo.azevedo@fgv.br
}

\begin{abstract}
Received theory (e.g. Hart, Shleifer, Vishny, 1997) suggests that the participation of private actors in the operation of public services (such as prisons) might create incentives for cost reduction at the expense of service quality. Given that the quality of correctional services is difficult to specify in contracts (e.g., the level of assistance to inmates), quality-enhancing initiatives may be neglected by private managers. We claim that private provision of public services by means of a "hybrid" mode - in which state-appointed supervisors are responsible for monitoring the operations of a private agent - does not experience such trade-off. We develop a model to describe the underlying mechanisms supporting such hybrid governance and conditions in which private operation with public supervision will be able to achieve satisfactory quality levels while still preserving incentives for cost reduction. Our model is supported by quantitative and qualitative evidence from prisons in Brazil. We observe that privately operated facilities by means of hybrid governance exhibit not only lower costs, but also superior service quality based on a broad set of performance indicators (order, security and services offered to inmates). We discuss implications for theory and for public policy in the context of public services.
\end{abstract}

\section{Key words}

Privatization, public governance, incomplete contracts, prisons

JEL Classification Codes: H11; L33; H41

Version: September 2007

\footnotetext{
* We thank the comments by seminar participants at Ibmec São Paulo, Centre ATOM - Univ. Paris 1 - Sorbonne and University of São Paulo (FEA/USP). All errors and omissions are our own.
} 


\section{Introduction}

In response to pressures towards efficiency in public services, we have observed several instances of private participation in the management of prisons. The intensity of that involvement varies according to legal and institutional issues, ranging from full privatization (such as in the United States, United Kingdom, Australia, South Africa) to hybrid privatepublic governance (Menard, 2004). In the latter, civil servants and private operators share the responsibility of running the prison; typically, private agents run the operations of the prison while a state-appointed supervisor (warden) monitors the overall service (Cabral, 2007).

Inspired by the French model, Brazil established its first outsourced prison in 1999. In 2007, there were 14 correctional facilities with private operation in five different states. ${ }^{1}$ In the Brazilian model, the government builds the facility, provides external protection (with armed guards), and assigns the warden of the prison. Private companies are responsible of supplying the remaining services necessary to the correctional facility operation (internal vigilance, meals, medical and judicial assistance, recreation and reinsertion activities, education, and so on). In return, private operators receive a fixed payment, according to the size of prison facilities, but independent of the number of inmates being held.

A critical question in this context is whether the outsourcing of operational activities in prisons to private agents outperforms the traditional mode involving full government-based management. Available studies on the theme are inconclusive; there is flagrant divergence among critics (Minhoto, 2000; Viggiano, 2002; Dilulio 1988, Wacquant, 2001; Nathan, 2003) and sympathizers of private participation on correctional activities (D’Urso, 1996; Oliveira, 2002; Logan 1990). None of these studies, however, focuses the comparison of public and private modes in terms of clear performance dimensions, such as the cost and the quality of

\footnotetext{
1 Those facilities house together roughly 6000 inmates, which represents 1,5\% of the Brazilian inmate population. (Cabral and Azevedo, 2008)
} 
the service. ${ }^{2}$ Differently, Hart, Shleifer e Vishny (1997) (henceforth HSV) propose a formal model to analyze how privatization might affect such performance dimensions. A key assumption of their model is that the contract between the government and the private service provider is incomplete; in particular, quality-based dimensions, such as the extent to which inmates receive adequate medical or legal assistance and the use of force as well are difficult to measure and hence are left unspecified. One of the main implications of the HSV model is that private managers will likely pursue cost reductions at expense of quality. Because the latter is hardly contractible and the compensation for the activities of the prison is fixed, private managers will have high-powered incentives to engage in cost-reduction efforts, thereby neglecting service quality improvements. In sum, privatization will likely be associated with a quality-cost trade-off.

We contend that such trade-off, as implied by HSV, does not hold for the hybrid mode of provision. The assignment of decisions rights to the state-appointed warden improves monitoring and reduces the effect of under-provision of non-contractible tasks, such as quality. This result only holds if the warden has incentives to guarantee a minimum level of quality associated with prison services, which is far from a straightforward result. As in the case of the private manager, the warden, as a public bureaucrat, receives a fixed wage and the pursuit of service quality is not specified in his labor contract. Furthermore, the private operator may bribe the warden to approve actions that reduce costs at the expense of quality. Hence, the presence of the public warden appears, at first glance, to be innocuous. We posit, however, that the state monitor may have implicit incentives to efficiently supervise the private manager. For instance, reputational concerns may induce the warden to guarantee appropriate levels of service quality and hence avoid triggering events that might lead to his

\footnotetext{
${ }^{2}$ In the economic literature, we can find the recent studies from Bayer and Pozen (2005) and Lukemeyer and McCorkle, (2006). Both studies investigate the prison privatization process in United States in a public versus private comparison.
} 
replacement (e.g., insurgence in the prison).

In this paper, we claim that, under certain conditions, the hybrid mode may solve the qualitycost dilemma. Key to this result is the existence of an implicit incentive by the public supervisor to effectively monitor the private operator such that satisfactory levels of quality are achieved. We develop a model to derive conditions in which such implicit contract may hold. We then present quantitative and qualitative evidence that is aligned with our prediction. Namely, we employ data from 13 publicly and privately operated prisons in the Paraná State, Brazil, observed from 2001 to 2006. In addition, we present two case studies of similar correctional facilities, one public and the other outsourced to a private company, both located in the Bahia State. In general, compared to fully state-managed prisons, privately operated units not only display lower costs but also superior quality performance indicators such as order, security and services offered to inmates - even after we control for prison-specific attributes such as characteristics of the correctional facilities and the nature of the inmate population. Thus, our study informs the discussion on how hybrid private-public management may be preferred to state-managed provision of public services in settings where contracts are incomplete.

Our paper is structured as follows. First, from a theoretical standpoint, we compare stateversus private-managed operations in terms of key performance dimensions - chiefly, cost and service quality - taking the HSV model as main reference. We next present a simple model to describe the underlying incentives within the hybrid private-public governance. To facilitate understanding, our theoretical discussion is grounded in our empirical context - i.e., the management of prisons. We then describe our empirical setting and present our results. Concluding remarks follow.

\section{Theory: contrasting state- and private-based management in the context of prisons}


In this section we analyze the relationship between the public service provider and the government as a contractual relationship affecting the performance of the service. In the context of prisons, two performance dimensions are relevant: cost and quality (HSV, 1997). Cost considerations have been used as a major justification for the privatization of public services in general, given the tight budget constraints faced by several governments. There is also increasing concern regarding the quality of public services. It is commonly argued that correctional facilities should be evaluated in terms of their capacity to receive inmates, maintain adequate living conditions, and guarantee that inmates are able to go back to society avoiding recidivism. It is also desirable to assure the provision of food, health and a safe environment that preserves the safety and integrity of inmates, employees, visitors and members of the external community (Archoembault and Deis, 1996). Quality-based performance indicators in prisons can thus be defined in terms of recidivism rates (proportion of individuals who commit new crimes), order and security within the facility (low levels of escapes, riots, deaths, assaults, etc.), and services offered to inmates (medical, judicial, social and psychological assistance, education, recreation, rehabilitation, etc.) (Cabral, 2007).

The contract established between the government and the manager of the prison (public or private) is intended to guarantee the attainment of those two performance dimensions. In fully state-owned and managed prisons, the government delegates the responsibility to run the facility to an appointed manager (warden), who manages a group of civil servants working in the prison. In fully privatized prisons, the government transfers the operation of the prison to a private operator, who is the solely responsible for the provision of all services necessary to run the facility. In some cases, private companies can also build the correctional facility. In hybrid governance modes, the private operator is responsible for most activities in the prison (including the provision of services to inmates and the execution of daily operations). However, in this particular case the warden is a civil servant who oversees the activities of the 
private manager within the prison. In other words, the principal (government) delegates the operation of the prison to a private company (the operator agent) and to a public manager as well (the supervising agent).

Each governance mode - state-managed, private-managed, or hybrid - will likely differ in their incentive intensity and the administrative controls that they impose. For ease of exposition, let us focus initially on the two polar modes: fully state-managed and fully private-managed prisons. Typically, private governance displays higher-powered incentives than public bureaucracies (Williamson, 1999). Private operators are residual claimants of the firm providing the public services: they typically receive fixed fee and are responsible for the expenses of the unit. Thus, private operators are expected to pursue a more efficient use of inputs such as labor, energy, and materials, leading to a reduction in the cost per inmate and an increase in the profit that they will attain from the operation. In contrast, public managers are not residual claimants and therefore do not have incentives to engage in cost-reducing actions.

Private operators can also employ more flexible labor contracts that allow for the infusion of high-powered incentives into the hierarchy. This is rarely observed in public bureaucracies. In some countries, such as in Brazil, legal constraints make it difficult to impose penalties or bonuses for civil servants. Labor contracts in the public sector tend to be more rigid and less responsive to performance targets. In publicly managed prisons, the replacement of employees is not automatic due to both bureaucratic procedures involving hiring and fiscal limitations by governments. In addition, changes in work shifts or in work procedures are more difficult to implement in civil servants. Furthermore, private companies do not need to follow rigid bureaucratic rules regarding purchasing procedures, which arguably decrease efficiency in procurement. 
The higher-powered incentives associated with private governance are, however, both a benefit and a cost for the privatization of public services. The same high-powered incentives that induce private managers to reduce costs can, at the same time, prompt them to neglect other performance dimensions such as quality. By aggressively reducing costs, prison managers can, for instance, reduce the level of medical or legal assistance to inmates. Arguably, the government could write a complete contract establishing targets for both cost and quality. Were those performance dimensions easily measurable, the solution to the problem of governance in public services would be trivial. Any observed performance below the initial target could mean the application of penalties such as fines, suspension of payments and even severance of the contract.

Hart, Shleifer e Vishny (1997) (HSV) inform this debate by arguing that quality-based performance dimensions are difficult to measure, write and enforce in contracts involving public services. In other words, the contract between the government and the private operator will likely be incomplete. For example, how to specify the adequate level of "force" employed by correctional officers against inmates, in cases of riots and internal insurgence? Also, it is difficult to contractually specify an adequate level of "treatment" of inmates in terms of food, medical services, legal support, and so on. Because private operators have residual control rights of the prison facility, they could easily engage in cost-reducing actions, even in cases where those actions would likely reduce quality standards. Although the HSV model presents conditions in which quality may improve under private management, the authors posit that "in important dimensions, such as prison violence and the quality of personnel, prison contracts are seriously incomplete" (p. 1152), and hence "a plausible theoretical case can be made against prison privatization” (p. 1154).

Now let us consider a hybrid management mode involving a private operator and a public manager (warden) within the facility. In this case, the public manager becomes responsible for 
the local supervision of the private manager and can, arguably, guarantee that the latter does not make decisions that reduce cost at the expense of quality. And if the private operator reduces quality, the public supervisor may recommend the severance of the contract. But then one question arises: does the warden have incentives to efficiently ratify decisions and monitor the private operator? Alchian and Demsetz’s (1972, p. 782) seminal question applies here: "who will monitor the monitor"? The warden is not a residual claimant of the public service and, hence, has no explicit incentive to guarantee low levels of costs and high levels of quality. Furthermore, corruption may be observed within the prison. For instance, when considering a cost-reducing initiative that will inefficiently reduces quality, the private operator may bribe the public warden to guarantee that the initiative is approved. Therefore, at least based on the standard assumptions of incomplete contracting models such as HSV, there is no reason to suppose that the hybrid management will avoid quality deterioration within the prison when private management is applied.

In sum, the baseline prediction derived from received theory is that prisons run by private operators - either fully privatized or hybrid - compared to public-managed ones, will likely present lower level of costs and also lower levels of quality performance indicators. Next we show that the equivalence of fully private and hybrid modes no longer holds when the public supervisor in the hybrid mode has an implicit contract with the government providing adequate incentives to monitor and enforce satisfactory quality levels. We also outline some conditions in which this implicit contract may hold. In the subsequent section, we evaluate our prediction based on empirical evidence from correctional services in Brazil.

\section{A simple model of hybrid private-public governance}

We propose a simple model that describes the mechanisms through which the hybrid mode may function. There are two players, the private operator running the prison, and the public 
supervisor (i.e. the warden) - a civil servant appointed to monitor the performance of the former within the correctional facility. The government agrees to compensate the private operator with a fixed fee $F$, which is paid each month after the performance of the prison is evaluated by the public supervisor. As we shall discuss below, the private operator will be able to pay a bribe $b$ to the public supervisor so as to receive the fee $F$ even if he fails to perform in terms of quality.

The private operator chooses effort levels to reduce the costs of the prison and to guarantee quality, denoted as $e_{x}$ and $e_{q}$ respectively, such that $e_{x}, e_{q} \geq 0$. As in HSV, we assume that quality is a non-contractible dimension; it is difficult to write a formal contract making the payment of the private operator contingent on the performance of the prison in terms of service quality. The monthly profit of the private operator is given by

$$
\pi=F-x\left(e_{x}\right)-C_{x}\left(e_{x}\right)-C_{q}\left(e_{q}\right),
$$

where $F$ is the fixed fee for the service; $x\left(e_{x}\right)$ is the level of operating costs of the prison as a function of the private operator's efforts to reduce costs, such that $x^{\prime}<0$ and $x^{\prime \prime} \geq 0 ; C_{x}\left(e_{x}\right)$ and $C_{q}\left(e_{q}\right)$ are the costs incurred by the private operator resulting from his exert effort to, respectively, reduce the operating costs of the prison and guarantee service quality. We assume that $C_{x}{ }^{\prime}>0$ and $C_{x}{ }^{\prime \prime}>0$, while $C_{q}{ }^{\prime}>0$ and $C_{q}(0)=0$. Given these assumptions, there is a level of effort to reduce operating costs, $e_{x}{ }^{*}$, that maximizes the monthly profit of the private operator, resulting from the first-order condition for maximization, $-x^{\prime}-C_{x}{ }^{\prime}=0$. From (1), we can also see that the profit-maximizing level of effort to guarantee quality is $e_{q}=$ 0 , which results from the fact that the private operator's payment (and, hence, profit) is not contingent on service quality. Therefore, for simplicity, we shall henceforth assume a binary decision by the private operator: he can either choose $e_{q}=0$ (e.g., no effort to guarantee quality) or $e_{q}=q$, where $q>0$ denotes the minimum level of service quality deemed acceptable by the government. 
The public supervisor, in turn, receives a monthly wage $w \geq 0$, net of his costs to exert effort within the prison and supervise the private operator. The reservation value of the public supervisor is zero. If the public supervisor accepts the bribe offered by the private operator, then he receives $w+b$.

The timing of the (monthly) game between the private operator and the public supervisor is as follows. The private operator begins by choosing between $e_{q}=0$ and $e_{q}=q$. If he chooses $e_{q}$ $=0$, the public supervisor observes the quality level and may punish the private operator for not meeting quality standards. Then the private operator is expected to get $\pi=-x\left(e_{x}^{*}\right)-$ $C_{x}\left(e_{x}^{*}\right)<0$ if he chooses $e_{q}=0$ and hence does not get paid.

The private operator may, however, bribe the public supervisor, in order to guarantee the fixed payment $F$ even in cases where service quality was low. The public supervisor can then either refuse to negotiate the bribe and therefore refrain from paying the fee $F$ to the private operator, or accept to negotiate the bribe and enter in a bargaining game with the private operator. Also for simplicity, we will assume that the private operator's reservation value is zero and that $F=x\left(e_{x}^{*}\right)+C_{x}\left(e_{x}^{*}\right)+C_{q}(q)$, so that the fixed fee received by the private operator is just sufficient to cover all costs associated with the service even when quality is adequate. Therefore, the rent captured by the private operator when he reduces quality is simply $C_{q}(q)$, which is the cost that is economized when service quality is zero instead of the level deemed acceptable by the government $(q)$. If there are no costs related to being bribed due to, for instance, social norms or implicit contracts -, any bribe $0<b<C_{q}(q)$ will hence be advantageous for both the private operator and the public supervisor. We will suppose a general solution for the bargaining game in which the public supervisor receives a fraction $\alpha$ 
$\in(0,1)$ of the private operator's rent, so that the final negotiated bribe will be $b=\alpha C_{q}(q)^{3}$. The structure of this game is represented in Figure 1.

\section{Figure 1: Game between public supervisor and private operator}

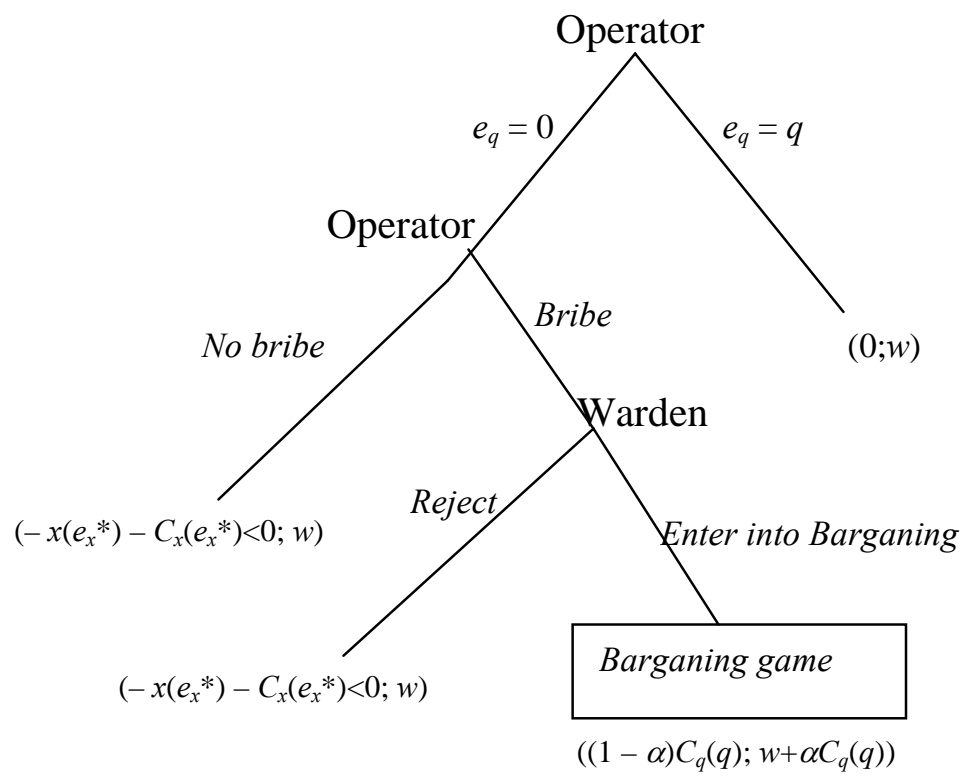

The unique subgame perfect equilibrium (SPE) of this one-shot game is straightforward. The public supervisor will always receive $\alpha C_{q}(q)$ in excess of his wage if he accepts to negotiate

\footnotetext{
${ }^{3}$ This assumption is more general than assuming a Nash Bargaining Solution or a bargaining game with alternating offers (Rubinstein, 1982). Our results hold for any bargaining solution in which both parties share the rent due to not meeting quality standards $\left(C_{q}(q)\right)$.
} 
the bribe, so he will prefer to do so. From (1), the private operator will therefore receive $\pi=F$ $-x\left(e_{x}^{*}\right)-C_{x}\left(e_{x}^{*}\right)-C_{q}(q)=0$ if he chooses $e_{q}=q$ and hence does not pay the bribe, or $\pi=F-$ $x\left(e_{x}^{*}\right)-C_{x}\left(e_{x}^{*}\right)-b=F-x\left(e_{x}^{*}\right)-C_{x}\left(e_{x}^{*}\right)-\alpha C_{q}(q)=(1-\alpha) C_{q}(q)$ if he chooses $e_{q}=0$ and negotiates the bribe with the public supervisor. So, in equilibrium, the private operator will choose $e_{q}=0$ and pay a bribe $b=\alpha C_{q}(q)$ so as to avoid that the public supervisor refuses to pay the fee $F$ for the service. The presence of the public supervisor is therefore functionally equivalent to the mode with the private operator and no public supervision whatsoever: there will always be an incentive for the private operator to reduce quality and collude with the public supervisor by sharing the gains resulting from the cost savings.

If the government wants to enforce an appropriate level of quality $e_{q}=q$, then it is important to make sure that the public supervisor will always refuse the bribe and penalizes the private operator who chooses low quality. How then to create incentives for the public supervisor to effectively enforce the quality dimension?

A possibility is that there might exist an implicit contract between the government and the public supervisor, based on reputational (career) concerns (see e.g., Baker, Gibbons, and Murphy, 1994). Suppose that the public supervisor has a labor contract with the government such as there is an infinitely repeated interaction with discount factor $\delta \in(0,1)$ - which can also be interpreted as the probability that the public supervisor will continue working for the government in each period. If the public supervisor refuses the bribe and monitors the private operator accordingly, he will get a present value of

$$
\text { (2) } \quad U_{\text {refuses }}=\frac{w}{1-\delta} \text {. }
$$

If, on the other hand, he accepts the bribe, he will get $w+\alpha C_{q}(q)$ in the current period and then become subject to retaliation thereafter. For instance, information about low service quality within the prison can be released to the public, increasing the pressure for the 
government to replace the public supervisor. We will assume that the probability that this retaliation will occur will be $\mu \in(0,1)$. With probability $\mu$, the public supervisor will be replaced if he fails to enforce the quality standards, getting his reservation value (zero) thereafter; ${ }^{4}$ with probability $1-\mu$, the public supervisor will not be replaced and he will therefore receive a payoff stream as before, discounted by one period. By accepting the bribe, the public supervisor will thus receive a present value of

$$
\begin{gathered}
U_{\text {accepts }}=w+\alpha C_{q}(q)+\delta(1-\mu) U_{\text {accepts }} \text {, which implies } \\
\text { (4) } U_{\text {accepts }}=\frac{w+\alpha C_{q}(q)}{1-\delta(1-\mu)}
\end{gathered}
$$

The public supervisor will refuse the bribe and enforce the quality dimension if $U_{\text {rejects }} \geq$ $U_{\text {accepts. }}$ Therefore, from (2) and (4), a superior SPE will be possibly reached - with $e_{q}=q$ and $b=0$ - if the government pays to the public supervisor a rent (wage net of costs of supervision) such that

$$
\text { (5) } \quad w \geq \frac{\alpha C_{q}(q)(1-\delta)}{\delta \mu} \text {. }
$$

Inequality (5) suggests some conditions that will affect the feasibility of the implicit contract with the government. First, the larger the discount factor $\delta$, the lower the minimum $w$ necessary to enforce the implicit contract. The establishment of a long-term labor contract between the government and the public bureaucrat may therefore help. Second, increases in $\mu$ decrease the minimum $w$ to support the implicit contract. The role of the press, human-rights organizations and public prosecution becomes crucial to increase the chance that information about low quality service within the prison will be disseminated to the public and put some pressure on the government to replace the public supervisor. Third, the minimum $w$ increases

\footnotetext{
${ }^{4}$ Arguably, the public bureaucrat may suffer an administrative prosecution and hence experience negative payoffs after being caught. Public Law imposes high penalties for improper behavior of civil servants. Since the probability and size of such penalties are difficult to specify ex ante, we assume for simplicity that the public supervisor gets his reservation value if his labor contract with the government is severed.
} 
with $C_{q}(q)$. Other things being equal, prisons in which the costs for the private operator to guarantee service quality are high - e.g., large prisons with dangerous inmate population should be more subject to collusion. In those conditions, the cost savings of the private operator will be so high that the bribe arrangement will be very attractive for both parties. Consequently, the rent that the government will need to pay to the public supervisor in order to enforce the implicit contract will need to be higher and may even become unfeasibly costly. $^{5}$ Thus, under certain conditions, we predict that, compared to state-owned prisons, units exhibiting hybrid governance will display lower costs but will not face a reduction in quality indicators.

However, a natural observation arises: instead of appointing a public supervisor to work within the prison, the government could directly enforce the quality of the prison by establishing an implicit contract with the private operator, instead of with the public supervisor. Note, however, that in our previous setting the fixed fee $F$ to the private operator would be such that he would get zero profit (his reservation value) if adequate service quality is achieved. Thus, to sustain an implicit contract with the private operator, the government will necessarily have to pay a fee above $F$. Suppose that the government pays $F+\Delta$, where $\Delta$ $>0$ is the rent received by the private operator in this new arrangement. From (1), the private operator now gets $\pi=F+\Delta-x\left(e_{x}^{*}\right)-C_{x}\left(e_{x}^{*}\right)-C_{q}(q)=\Delta$ if he chooses $e_{q}=q$, or $\pi=F+\Delta-$ $x\left(e_{x}^{*}\right)-C_{x}\left(e_{x}^{*}\right)=\Delta+C_{q}(q)$ if he chooses $e_{q}=0$ and hence avoids incurring the costs to achieve adequate service quality. Similarly as before, we will assume an infinitely repeated interaction with discount factor $\delta$ and a probability of $\mu$ that low quality will be detected and hence trigger retaliation (severance of the contract with the private operator). Therefore, an SPE with $e_{q}=q$ will be possibly reached in this case if

\footnotetext{
${ }^{5}$ We note that, as well known from the theory of infinitely repeated games, the inferior equilibrium where $e_{q}=0$ is not ruled out. Effective pre-play communication will need to occur; for instance, the government must make it clear for the public supervisor what is expected from the service and what will be the consequences if any information about low quality within the prison is detected.
} 


$$
\text { (6) } \Delta \geq \frac{C_{q}(q)(1-\delta)}{\delta \mu} \text {. }
$$

Comparing conditions (5) and (6), we can see that the minimum rent necessary to support the implicit contract with the private operator $(\Delta)$ is larger than the minimum rent that the public supervisor will need to receive. It is easier to sustain a implicit contract with the public supervisor than (directly) with the private operator precisely because the "temptation" to defect (choose low quality) of the latter is higher. By defecting, the private operator saves the costs to guarantee quality $\left(C_{q}(q)\right)$ altogether. In the former arrangement, the public supervisor, by accepting the bribe, gets only a fraction $\alpha$ of this value, which results from his negotiation with the private operator. This feature provides an advantage for the hybrid mode compared to the mode of privatization without public supervision by a delegated bureaucrat. In addition, the lower the bargaining power of the public supervisor, the lower the fraction $\alpha$ will be, and as a consequence the higher will be advantage of the hybrid mode.

Other factors, outside the present model, may also favor the hybrid model with public supervision. For instance, the hybrid model of privatization may be, from a political standpoint, easier to implement that the full-fledged mode of privatization without public supervison within the prison. In Brazil, for instance, non-governmental groups are highly critical with respect to private participation in prison management. Keeping a public supervisor within the prison helps attenuate such criticisms. Another source of advantage for the hybrid mode, also not modeled here, is related to social norms associated with public services. We modeled the implicit contract between the government and the public supervisor as an infinitely repeated game based on reputational concerns. However, implicit contracts may also be supported by social norms affecting agents’ preferences (e.g., Kandel \& Lazear, 1992). Thus, the public supervisor may find professionally unacceptable to engage in any type of collusion with the private operator - as implied, for instance, in the Weberian theory of 
bureaucracy.. Considerations about professionalism in public services may therefore provide an additional support for the effectiveness of the hybrid mode (Miller, 2000).

Next we analyze data from public and hybrid modes of correctional facilities in Brazil in order to verify some of the predictions stated herein.

\section{Empirical evidence: hybrid public-private governance of prisons in Brazil}

Obtaining information about the prison service is not trivial. Lack of consolidated data, inappropriate recording process and barriers imposed by bureaucrats and government officials are some of the main reasons that might discourage researchers to investigate the sector. Consequently, empirical studies in the correctional services are not usual. In the present paper, we analyze two cases of hybrid management in Brazil. The first one is the experience of Paraná State (located in Brazil's South region), which combines quantitative and qualitative data. The second case is more qualitative-oriented and refers to the experience of the Bahia State (located in Brazil’s Northeast region). In the latter, we compare two similar prisons: one entirely managed and operated by local government and another whose operations where outsourced to a private operator monitored by a public supervisor. When we analyze both states separately, we are able to control key institutional effects such as differences in regulation, influence of local political parties, rules for prisoners, and so on.

\subsection{Outsourcing of prison operations in Paraná}

Paraná pioneered the adoption of privately operated facilities in Brazil in 1999. This experience motivated us to gather data from managerial reports of the Paraná State Correctional Administration Department (DEPEN-PR) and from contracts between government and private operators. The database contains 65 observations of 13 correctional facilities to convicted individuals from 2001 to 2006 (seven publicly and six privately operated). Thus, our database has a panel structure. In addition, we have examined contracts, 
official documents and legal procedures. We have also conducted 11 semi-structured interviews with prison managers of publicly and privately operated facilities and with the staff of DEPEN.

The privately managed prisons in Paraná are best categorized as a hybrid mode of governance. The government is responsible for the construction of the facility and appoints a warden to supervise the operations of the private service provider. Besides the warden, other civil servants work within the prison: a vice-warden, a security manager and some guards in charge of the external vigilance. These guards carry weapons and can use the lethal force if, for instance, some prisoner tries to evade. The private service provider, in turn, receives a fixed fee for the operation, proportionally to the number of inmates within the prison. The private operator becomes responsible for the internal vigilance of the unit, as well as the provision of food, medical and judicial assistance, recreation and reinsertion activities, education, and so on. The contracts signed between the local government and private operators do not incorporate quality standards. Targets and minimum requirements regarding performance indicators are not present as well. Thus, as in the HSV model, the contracts herein analyzed are incomplete.

Regarding costs, we only had access to information from 2004. This was the only year when the Paraná State Correctional Administration Department (DEPEN-PR) made efforts to consolidate the necessary data to perform comparisons. In this period, the monthly average costs per inmate in privately operated facilities were $\mathrm{R} \$ 1,266$ per inmate (US\$ 506 considering the correspondent exchange rate at that time). As for state-managed prisons, by using the same cost drivers (labor costs, materials, water, energy, communication expenses, etc.), estimates indicate that costs would be about R \$ 1,387 per inmate (US\$ 555) e.g., 10\% higher than in the case of private-managed prisons. The calculations above were made by the DEPEN-PR staff and provided to the authors. Although we do not have information on costs 
for other years, our interviews commonly expressed that privately managed prisons are more efficient in terms of costs.

We do have, however, quantitative, prison-specific data involving proxies for quality for all the years in our panel. We focus on quality indicators related to order/security (escapes and deaths) and services to inmates (medical appointments and legal advisory). Although there may be other quality aspects that we do not assess in our study, such as recidivism rates, our indicators apparently capture most concerns related to the private management of prisons in Brazil. Namely, lack of assistance within the prison has been voiced as one of the main causes of prisoners’ complaints in the Brazilian context.

Tables 1 and 2 present the variables that we use in our study. Table 1 describes our indicators of quality in the correctional service. Simple mean comparison tests reveal that, in the privately operated prisons, levels of quality are significantly superior for all indicators except the measure related to the provision of legal assistance. Table 2, in turn, describes the independent variables used in our subsequent analysis.. Table 2 also presents a set of variables that allow us to control for differences in technology and characteristics of inmates across prisons. For instance, we observe that publicly operated prisons tend to hold more inmates and are older than privately operated facilities $(p<0.01)$. Indeed, all facilities with private operation were established between 1999 and 2002. The newest facilities (either with public or private operation) follow the latest standards of correctional services, notably displaying a lower number of inmates held.

Thus, we believe it is necessary to contrast the levels of service quality across prisons after we control for prison-specific differences in a multiple regression context. Also, due to the fact that our data have a longitudinal nature - i.e., we observe the levels of quality across prisons over time - we employ panel data regressions (Wooldridge, 2006). Our methods are discussed next. 
Insert Table 1 about here

Insert Table 2 about here

\subsubsection{Regression model}

We model the performance of each prison as a function of its governance structure (captured by the dummy variable OUTSOURC), controlling for prison-specific attributes, as follows:

$$
y_{i, t, d}=f\left(\text { OUTSOURC }_{i}, \psi_{i, t}, \phi_{i, t}\right),
$$

where $y_{i, t, d}$ stands for the performance of prison $i$ at year $t$ regarding the quality indicator $d$ (e.g., level of medical assistance), $\psi_{i, t}$ refers to characteristics of the prison, and $\phi_{i, t}$ refers to characteristics of the inmate population.

Given the nature of our data, we employ panel-data regressions with random effects. This method assumes that non-observed effects do not have any correlation with the remaining independent variables. We were unable to use a fixed-effects specification because we do not have instances of prisons which exhibited both hybrid and public governance during the time frame of our data. Therefore, the variable OUTSOURC does not have within-prison variance. To be sure, the assumption of the random-effects model that the error term is not correlated with the independent variables might be violated in our case. Namely, prison-specific characteristics might influence both the decision to outsource the operations and the performance of the prison, thereby leading to spurious estimates. For instance, some suggest that Brazilian prisons whose operations were outsourced to private managers display some advantages as compared to their public counterparts because they hold less dangerous criminals. In other words, privately operated facilities could eventually present superior 
quality indicators because the internal management was easier at the outset and not because of improved management. Also, some argue that privately managed prisons in Brazil tend to be newer than state-managed units. Improved conditions within newer prisons may therefore make quality targets easier to achieve than in older prisons. The inclusion of prison- and inmate population-specific controls in our regressions intends precisely to avoid such kinds of spurious relationships. We are not aware of any other prison-specific attribute, beyond the control variables already included in our study and described in Table 2, which might induce spurious inference regarding the effect of governance on performance. With proper controls, the use of random-effects estimates is warranted (Wooldridge, 2006).

The specification of the random-effects model used in our study varies according to the type of qualitative indicator employed as a dependent variable. In the case of the performance indicators related to the assistance that inmates receive - medical assistance (MED_ASSIST) and legal assistance ( $\left.L E G A L_{-} A S S I S T\right)$ - we employ the standard generalized least squares random-effects model. Although received theory (e.g., the logic following from the HSV model) suggests that prisons where operations are outsourced to private managers will exhibit lower levels of medical and legal assistance, our model presented in section 3 predicts the opposite; that is; the coefficient of OUTSOURC will be non-negative. Regarding the other qualitative indicators related to safety and order - number of escapes (ESCAPES) and deaths $(D E A T H)$ - we adopt another estimation approach. These indicators involve count data originated from rare events, thereby displaying a large quantity of zeros. In this condition, McCullagh and Nedler (1989) suggest the use of the Poisson generalized linear model, estimated via maximum likelihood. The response variable, in the Poisson regression, follows an exponential probability distribution function. Although received theory suggests that prisons where operations are outsourced to private managers will exhibit higher levels of escape and death, our model implies that the coefficient of OUTSOURC will actually be non- 
positive.

\subsubsection{Results}

Let us analyze first the effect of governance on safety and order indicators. Table 3 shows the Poisson estimates with random effects. Dependent variables are the number of escapes and deaths observed in the prison during the period under analysis. In both cases, we perform alternative estimations as a way of observing changes in the effects when new variables are added. We observe that, controlling for variables related to characteristics of the correctional facility $\left(\psi_{i, t}\right)$ and characteristics of the inmate population $\left(\Phi_{i, t}\right)$, private management of prisons is negatively associated with the incidence of deaths and escapes at conventional significance levels. With respect to privately operated facilities, if we leave other variables at their sample means (see Tables 1 and 2), we have 41\% less predicted probability of experiencing deaths as compared to a publicly managed prison in the same conditions. In the same line, the probability of experiencing escapes in a privately operated facility is $99 \%$ lower. $^{6}$

As an ancillary result, we observe that the fraction of inmates involved with labor activities has an important impact in reducing the number of death records. In addition, as one would expect, prisons with greater percentage of less dangerous inmates are associated with a lower number of escapes. Surprisingly, overcrowding rates do not correlate at conventional significance levels with deaths and escapes.

Insert Table 3 about here

Table 4, in turn, shows estimates where services provided to inmates - number of medical and legal appointments per inmate-year - are taken as dependent variables. In the case of medical

\footnotetext{
${ }^{6}$ In a Poisson regression model, the interpretation of coefficients can be made by using the respective antilogs. If $x_{k}$ is a binary variable ranging from 0 to 1 , the expected change is $\exp \left(\beta_{k}\right)-1$. If one keeps all other factors constant, it is necessary to multiply the above result by 100 in order to obtain the discrete change percentage (Wooldridge, 2006).
} 
assistance, we observe that publicly operated prisons provide a lower number of medical appointments to inmates, compared to their private counterparts, when we focus on prisons for convicted criminals. Thus, in this case private management tends to be positively associated with the level of medical service. However, estimation 4 shows that observed outcomes do not differ between two modes, when we consider the two types of facilities - for convicted criminals (penitentiaries) and for individuals awaiting trial, sentencing or assignment to a penitentiary (temporary detention center). In all estimations, overcrowding rates are strong correlated with medical assistance. We can also observe that facilities with superior number of dangerous inmates and with higher proportion of prisoners working in the facilities provide more medical appointments.

Corroborating the descriptive statistics reported in Table 1, the number legal advisories offered to inmates does not differ in the two modes of governance. Apparently, only the extent of overcrowding has a significant impact on the level of legal assistance. Under these circumstances, special attention is given by prison attorneys in order to decrease the length of time prisoners spend behind bars so that more legal advisories are provided. Actually, the higher the proportion of inmates locked-up in the same physical space, the higher is the probability of riots and other modes of insurgence. Thus, the efficiency of legal matters is crucial to pacify the turbulent correctional environment.

We conclude that the data from prisons in Paraná supports our model: we cannot say that quality indicators differ across hybrid- and public modes of governance. Actually, for some indicators (such as medical assistance), the quality provided by the hybrid mode of governance appears to be even superior.

Insert Table 4 about here 


\subsection{Outsourcing of prison operations in Bahia}

Following the Paraná initiative, the Bahia State started outsourcing prison services in December 2002. In 2007, there were five privately operated prisons in the State. In this section, we try to identify the differences in the public and in the hybrid modes of provision, by comparing two similar prisons, sharing the very same design and size: The Penal Complex Teixeira de Freitas (CPTF), publicly operated, and The Penal Complex of Valença (CPV), privately operated. ${ }^{7}$ Both prisons are located in rural areas and present inmates with similar criminal backgrounds (the vast majority were found guilty of crimes against people, i.e., murders and attacks). These similarities allow us to compare the outcomes of the two prisons, controlling for those variables.

We collected data from the Bahia State Penal Affairs Direction for the years 2003 and 2004 and also qualitative information from 18 interviews with several actors (wardens, correctional officers, members of judiciary, government officials, managers of the private firm operating the prison, politicians and union leaders). We compare three types of performance indicators: administrative; security and services to inmates. Unfortunately, we did not have access to detailed cost information, so that the present comparison focuses mainly on the quality dimension. However, the data show that the public managed prison employs more labor to run the prison (20\% more), as compared to privately operated facility. Also, absenteeism rates in public prison are three times higher and wages of the correctional officers in the outsourced prison were $60 \%$ less than that of the civil servants in the public facility. Furthermore, evidence on the use of other inputs indicates that the public prison is less efficient: it spent three times more on water and electricity than the private company and invested $50 \%$ less than the private operator in the maintenance of the facility over the same period. Collectively, these figures suggest that costs are higher in the public operated prison.

\footnotetext{
${ }^{7}$ The contract between the Bahia State government and the private operator presents the same characteristics of the contracts in the Parana State.
} 
When we focus on security performance indicators, we observe that outcomes differ across the two prisons. While zero escapes or escape attempts were recorded in the prison with hybrid governance, in the public prison there were occurred 8 escapes and 25 escape attempts. In the same period, one riot occurred in the privately operated prison ${ }^{8}$ and none was recorded in the publicly-managed facility. Regarding the number of assaults, evidence also runs against the publicly operated prison: during 2003 and 2004, the public facility recorded 8 assaults against employees, while the privately-operated recorded none. In the same period, the number of assaults among inmates was 12 times higher in the public facility.

Last, the services provided to inmates are about to be superior in the privately operated facilities. Like in the Paraná case, the average number of medical assistance per inmate is 10 times higher in the privately operated prison, while the level psychological assistance is $80 \%$ higher, when we compare the number of appointments provided. Also, the level of legal assistance to inmates - a critical service in the correctional system, because it relates to the propensity of releasing or not an inmate - is 20 times higher in the privately operated prison (10764 appointments versus 504 in the public prison). We note that the privately-operated prison provides this service by using its own lawyers, while in the publicly-operated one public attorneys are the only source of legal advice to inmates who cannot afford a private lawyer. The reduced number of available public attorneys helps explain this gap. ${ }^{9}$ The only variable that the public prison achieved better performance was dental assistance, with a level 9\% higher than its private counterpart.

Insert Table 5 about here

\footnotetext{
${ }^{8}$ The private operator paid for the correspondent expenses (equivalent to US\$15,000).

${ }^{9}$ More details regarding the experience of outsourcing of prison services in Bahia State can be found in Cabral and Azevedo (2008).
} 
In sum, as in the case of prisons in the Paraná State, we have evidence that quality indicators are not inferior in the privately operated prison; in fact, they appear to be superior in general.

\section{Explaining the performance of the hybrid governance}

The results above indicate that privately operated correctional facilities present, in general, lower costs and similar or improved quality indicators as compared to publicly managed units. Although we do not find significant differences with respect to legal assistance, we can safely conclude that no support is found for received theories, such as the HSV model, which suggest that fully private or hybrid governance of prisons should exhibit lower levels of quality indicators than public ones.

Our empirical results are consistent with our claim that the presence of publicly appointed officials within the prison helps assure adequate levels of service quality. If the public supervisor effectively monitors the private operator, then the hybrid mode is expected to not only exhibit lower costs, but also avoid the quality-cost tradeoff proposed by received theory. The formal separation between operation and supervision by the state-appointed warden facilitates the application of penalties in case of contractual defection by the private operator. For instance, after observing that the private operator reduced the level of assistance to inmates, the warden may not authorize the payment of the invoices and even recommend the severance of the contract with the private manager.

As discussed before, this separation of decision rights is not a sufficient condition for better performance since the private operator has an incentive to bribe the public supervisor. As in the contract between the private operator and the government, the (labor) contract between the government and its representative within the prison (the warden) is also incomplete. Although

the warden can ratify and monitor the actions of the private operator, he is not a residual claimant of the specific correctional unit and, hence, does not have explicit incentives to 
enforce efficient actions within the prison. Furthermore, to approve certain cost-reducing actions or avoid severance of the contract, the private operator might bribe the public manager. Hence, in the absence of implicit incentives, the threat to discontinue the service in case of reduction of quality standards is likely non-credible. Thus, it is worth searching for evidence that might indicate the existence of such implicit contract in the Brazilian case.

Section 3 presented a model that formalized the effect of reputational concerns, but also suggested the possible effect associated with social norms; in fact, these two effects may occur together in practice (e.g., Lazzarini, Miller and Zenger 2004). Consider first the effect of reputation: our model suggests that the implicit contract between the public official and the government will hold when there is a long-term labor contract associated with an idiosyncratic rent (efficiency wage); when there is a high probability of pressure from external constituencies (the press, as well as religious and nonprofit organizations, for instance) to replace the management if quality deteriorates; and when the costs to guarantee quality within the prison are not very high.

We do observe that labor contracts in the public service are very long-term. In fact, careers in the public sector in Brazil not only have indeterminate termination date, but also are difficult to be severed except in cases of strong external pressure. Furthermore, as we could observe in our qualitative interviews, individuals involved in commissioned positions, such as the warden, receive in most cases an excess income of around $40 \%$ above his regular wage. Furthermore, good performance in commissioned positions enlarges career opportunities in the public service. This feature creates an implicit incentive similar to an efficiency wage within the public administration. However, the implicit contract is subject to termination in case of bad performance. Some appointed wardens are not civil servants with job stability. Misconduct may therefore lead to replacement of the warden from his duty within the prison. The experience in Brazil also reveals that riots and mistreatment in prisons is oftentimes 
detected and disseminated by the press. The probability of being dismissed or being prosecuted for improper behavior (e.g. corruption or failure to perform his obligations) is, in general, larger in correctional services than in other types of public service. External monitoring by public prosecutors and human rights organizations is intense. An increase in such external pressure tends to increase the probability that the warden will be fired (i.e., variable $\mu$ increases), thus reducing the likelihood of collusion between the public supervisor and the private operator. Indeed, in one of the privately operated prisons $<<$ in Paraná?>>, a warden was fired due to escalating pressure from external constituencies arguing that he was abusing of violence against inmates. Furthermore, the restricted discretionary power of public officials, which has the downside of reducing efficiency in procurement and management, actually guarantees that they will focus on prescribed tasks. In Brazil, for instance, the Public Law prohibits civil servants to perform any task not previously assigned by law or regulatory norms, making it easier for public prosecutors to identify any misconduct..

Finally, we have evidence that correctional facilities with the hybrid governance mode tend to display features that make, on average, the attainment of satisfactory quality easier. For instance, in Paraná publicly operated prisons tend to hold more inmates. It seems that, on average, “easier” prisons were more frequently used for the hybrid mode of governance which is consistent with our theoretical prediction that the implicit contract between the government and the public official tends to be more feasible when the cost of meeting quality standards is not very high. We note, however, that the superiority of some quality indicators in Paraná was observed even after controlling for this effect through regressions with control variables, given that we have sufficient heterogeneity of prisons in terms of characteristics of the inmate population.

The implicit contract between the government and the warden may also be supported by social norms. The warden may have internalized values of integrity and honesty when dealing 
with public matters. In fact, the government may likely appoint as public supervisors bureaucrats with historical record of integrity and honesty in previous jobs within the civil service. Actually, the very fact that the warden is no residual claimant of the prison may help. Without high-powered incentives to pursue cost reductions, the desire to guarantee high levels of quality, supported by internalized values, may become a particular objective of the public official within the prison (see, along these lines, Miller, 2000).

In our empirical investigation, we could observe that nominated wardens and their respective vice-wardens have large experience with correctional activities. People with different professional backgrounds manage the prisons, such as public attorneys, psychologists, public administrators, police officials, retired members of judiciary. For instance, the warden of the hybrid prison in Bahia was an experienced policeman who successfully dealt with different cases of kidnapping and rebellion. The nomination requires the ideological alignment between candidates and bureaucrats of the Correctional Administration Department. Thus, let us suppose that the governmental orientation for correctional policies is towards security (e.g. to guarantee a safe environment inside the prison), combined with reinsertion efforts. In this vein, an individual who believes, for instance, in the sole use of force will hardly be appointed for the job. In fact, the mere act of assigning civil servants who are not intrinsically committed to meet the desired standards may represent a high political cost to government officials.

We thus believe that the empirical results are consistent with our claim that hybrid forms of governance may avoid the quality-cost trade-off associated with correctional services. Our evidence is also consistent with the view that an implicit contract between public officials and the government is the key underlying mechanism guaranteeing an effective enforcement of quality standards within prisons. ${ }^{10}$

\footnotetext{
${ }^{10}$ As a curiosity, despite the superior results obtained by the private governance of prisons, surprisingly the Paraná State Government decided in 2006 to stop the experience with privately operated facilities. In particular,
} 


\section{Conclusions}

Prison service is not an activity that has attracted the attention of scholars. However, the comparative assessment of private versus public modes of governance in more microanalytic contractual terms is scant. As a result, we know relatively little about how contracts associated with public services work, especially in settings, as ours, involving hybrid governance. Our paper contributes to fill this gap.

Based on an incomplete contract framework, our analysis showed that the hybrid privatepublic governance not only display lower costs, but also similar or improved performance on a broad range of quality indicators - e.g., reduced number of deaths, low number of escapes, and better medical assistance to inmates as compared to the traditional, public mode of governance. Apparently, the superiority of the private operation in our context is due to the hybrid arrangement that allocates residual rights of control to a state-appointed public supervisor. Hybrid modes present distinct incentives structures as compared to public modes of provision and are not constrained by bureaucratic rules of civil service. In particular, the presence of the public supervisor within the prison, with implicit incentives to effectively monitor the private operator, guarantees that satisfactory quality standards are met. As compared to the full privatized model described by HSV, the hybrid form described in our study provides more efficient monitoring and restricts opportunistic behavior by the private operator.

The importance of monitoring shows us that the sole choice between public or private governance itself is not enough for obtaining improvements in public services. We posit that the attainment of superior performance in correctional services results from the creation of

the re-elected governor publicly opposed private participation in public services provision for ideological reasons. Former outsourced prisons were transferred back to public administration. Although this should provide an interesting empirical material for future work, an analysis of the pertinence and the implications of such measure is beyond the scope of our study. 
proper governance structures designed to provide at the same time high-powered incentives for cost reduction and efficient monitoring to guarantee high quality standards in the process of contractual execution. The implications for the design and organization of public services become evident. Future research should therefore examine hybrid modes of governance (Menard, 2004) in other contexts, such as water supply, sewerage service, and ports, among other public utilities This research agenda may shift the attention from the usual choice of public versus private governance towards a more microanalytic examination of the mechanisms that could deliver high performance in the several dimensions of interest in public services.

\section{References}

AGHION, Philippe; TIROLE, Jean. (1997) "Formal and Real Authority in Organizations," Journal of Political Economy, University of Chicago Press, vol. 105(1), 1997, pages 1-29.

ALCHIAN, A.; DEMSETZ, H (1972). Production, Information Costs, and Economic Organization The American Economic Review, Vol. 62, No. 5, 777-795

ARCHEOEMBEAULT, W.G. and DEIS, D.R. (1996). Cost-Effective Comparisons of Private Versus Public Prisons in Lousiana: A comprehensive analysis of Allen, Avoyelles ad Winn Correctional Centers. Research paper. Lousiana State University, 79 p

BAKER, G.; GIBBONS, R.; MURPHY, K. (1994) "Subjective performance measures in optimal incentive contracts" The Quarterly Journal of Economics, v. 109, n. 4, p. 1125-56.

BAYER, Patrick; POZEN, David (2005) "The effectiveness of juvenile correctional facilities: public versus private management” Journal of Law and Economics. vol. XLVIII, October, p.549-589.

CABRAL, Sandro (2007). Sobre a participação privada na gestão e operação de prisões no Brasil: uma análise à luz da Nova Economia Institucional. Organizações e Sociedade v.14, jan-mar, 29-47.

CABRAL , Sandro, AZEVEDO, Paulo (2008) "The modes of provision of prison services in a comparative perspective”. Brazilian Administration Review, Forthcoming

DEMSETZ, H. (1968) “Why regulate utilities?” Journal of Law and Economics, v.11, April, p. $55-66$ 
DILULIO, J.J. (1988) “What is wrong with private prisons”. Public Interest. 92, Summer.

D’URSO, Luiz Flávio Borges (1996) A Privatização dos Presídios (Terceirização). Faculdade de Direito da Universidade de São Paulo - USP, (Dissertação de Mestrado), 247 p.

MILLER, G. J. (2000) “Above politics: credible commitment and efficiency in the design of public agencies” Journal of Public Administration Research and Theory, vol. 10, n. 2, p. 289328.

HART, Oliver; SHLEIFER, Andrei e. VISHNY, Robert W. (1997) "The Proper Scope of Government: Theory and an Application to Prisons.” The Quarterly Journal of Economics. vol. 112, n.4, nov., p. 1127-1161.

KANDEL, Eugene; LAZEAR, Edward. (1992). “Peer Pressure and Partnerships” Journal of Political Economy, v. 100, 801-816.

LAZZARINI, S.; MILLER, G.; ZENGER, T. (2004) “Order with some law: complementarity versus substitution of formal and informal arrangements" Journal of Law Economics and Organization, v. 20, n. 2, 261-298

LOGAN, Charles H. (1990) Private Prisons: Cons and Pros. Oxford University Press, 1990, $437 \mathrm{p}$.

LUKEMEYER, Anna; McCORKLE (2006). "Privatization of Prisons: Impact on Prisons Conditions” American Review of Public Administration. v.36, n.2, June, 189-206.

MARIMORT, David; DE DONDER, Philippe e DE VILLEMEUR, Etienne (2005). “An incomplete contract perspective on public good provision”. Journal of Economic Surveys v.19, n.2, p.149-180.

McCULLAGH, P. e NEDLER, J.A. (1989). Generalized Linear Models. Chapman and Hall, $2^{\text {nd }}$ edition, $511 \mathrm{p}$.

MÉNARD, Claude (2004) "The economics of hybrid organizations." Journal of Institutional and Theoretical Economics 160(3), p. 1-32.

MINHOTO, Laurindo Dias (2000). Privatização de presídios e criminalidade: a gestão da violência no capitalismo global. São Paulo: Editora Max Limonad, 214 p.

NATHAN, Stephen. "Private Prisons: Emerging and Transformative Economies” In. Coyle, Andrew; Campbell, Alisson; Neufeld, Rodney (ed.) Capitalist Punishment: Prison Privatization and Human Rights. Atlanta: Clarity Press, 2003a, ch. 16. 189-201.

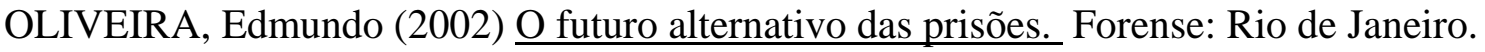

RUBINSTEIN, Ariel. (1982). "Perfect Equilibria in a Bargaining Model”, Econometrica, 50, p. 97-109.

VIGGIANO, Fernando Braga (2002) "Endurecimento das penas e da execução penal: retrocesso inigualável”. In: Revista de Informação Legislativa. Brasília, n.156, out/dez 2002, 
p.25-31.

WACQUANT, Loïc (2001). As prisões da miséria. Jorge Zahar Editor, Rio de Janeiro, 174 p.

WILLIAMSON, Oliver (1999) "Public and Private Bureaucracies: A Transaction Cost Economics Perspective”. Journal of Law, Economics and Organization. Mar, 15:1.pp-306342.

WOOLDRIDGE, Jeffrey (2006). Introdução à Econometria: Uma abordagem moderna. São Paulo: Pioneira Thomson Learning. 684 p. 
Table 1: Dependent variables (service quality indicators)

\begin{tabular}{|c|c|c|c|c|c|c|c|}
\hline $\begin{array}{l}\text { Type of } \\
\text { indicator }\end{array}$ & Variable & $N$. & Mean & $\begin{array}{l}\text { Mean } \\
\text { public } \\
(N=38)\end{array}$ & $\begin{array}{l}\text { Mean } \\
\text { private } \\
(N=27)\end{array}$ & $\begin{array}{l}p \text {-value } \\
(t \text { test })\end{array}$ & Description \\
\hline $\begin{array}{l}\text { Security } \\
\text { and order }\end{array}$ & $E S C A P E S^{11}$ & $\begin{array}{l}64 \\
65\end{array}$ & $\begin{array}{l}0.56 \\
0.8\end{array}$ & $\begin{array}{l}0.895 \\
0.895\end{array}$ & $\begin{array}{l}0.077 \\
0.667\end{array}$ & $\begin{array}{l}0.0251^{* *} \\
0.7081\end{array}$ & $\begin{array}{l}\text { Number of evaded } \\
\text { prisoners from the } \\
\text { correctional facility in } \\
\text { each year. }\end{array}$ \\
\hline $\begin{array}{l}\text { Security } \\
\text { and order }\end{array}$ & DEATH & 65 & 1.06 & 1.47 & 0.48 & $0.0976 *$ & $\begin{array}{l}\text { Number of deceased } \\
\text { prisoners in the } \\
\text { correctional facility in } \\
\text { each year. }\end{array}$ \\
\hline $\begin{array}{l}\text { Services to } \\
\text { inmates }\end{array}$ & $M E D \_A S S I S T^{12}$ & $\begin{array}{l}43 \\
65\end{array}$ & $\begin{array}{l}4.51 \\
5.14\end{array}$ & $\begin{array}{l}3.44 \\
5.18\end{array}$ & $\begin{array}{l}5.86 \\
5.07\end{array}$ & $\begin{array}{l}0.002 * * * \\
0.9221\end{array}$ & $\begin{array}{l}\text { Number of medical } \\
\text { appointments in the } \\
\text { prison per inmate-year }\end{array}$ \\
\hline $\begin{array}{l}\text { Services to } \\
\text { inmates }\end{array}$ & $L E G A L \_A S S I S T$ & $\begin{array}{l}43 \\
65\end{array}$ & $\begin{array}{l}7.26 \\
8.11\end{array}$ & $\begin{array}{l}6.94 \\
8.72\end{array}$ & $\begin{array}{l}7.66 \\
7.25\end{array}$ & $\begin{array}{l}0.6904 \\
0.2957\end{array}$ & $\begin{array}{l}\text { Number of legal } \\
\text { appointments in the } \\
\text { prison per inmate-year }\end{array}$ \\
\hline
\end{tabular}

Note: $* p<0.10 * * p<0.05^{* * *} p<0.01$

\footnotetext{
${ }^{11}$ In some calculations, we have omitted one observation from "escapes” variable. The non-considered event is related to a massive evasion organized by an external criminal gang. The inclusion of this outlier generates distortions in the analysis.

${ }^{8}$ Medical assistance and legal advisory indicators are greater in temporary detention centers (for individuals awaiting trials, sentences or assignment to other penitentiaries) as compared to prisons to convicted inmates, whatever the adopted governance structure (public or private). The reasons for that are related to the fact that in the latter the turnover is higher, once inmates remain less time within such prisons. As a consequence, more medical appointments and legal advisories are required in these facilities In this way, some of our comparisons will address the latter type of correctional facilities, which represents 43 observations (24 in publicly and 19 in privately operated facilities).
} 
Table 2: Independent variables

\begin{tabular}{|c|c|c|c|c|c|c|c|}
\hline Variable & Variable & $N$. & Mean & $\begin{array}{l}\text { Mean } \\
\text { public } \\
(N=38)\end{array}$ & $\begin{array}{l}\text { Mean } \\
\text { hybrid } \\
(N=27)\end{array}$ & $\begin{array}{l}p \text {-value } \\
(t \text { test })\end{array}$ & Description \\
\hline \multicolumn{8}{|c|}{ Hypothesized variable } \\
\hline $\begin{array}{l}\text { Related to } \\
\text { governance }\end{array}$ & OUTSOURC & 65 & 0.415 & - & - & - & $\begin{array}{l}\text { Dummy variable related to } \\
\text { mode of governance: } 1 \text {, if } \\
\text { prison is privately operated } \\
\text { with public supervison } \\
\text { (hybrid); } 0 \text {, if public. }\end{array}$ \\
\hline \multicolumn{8}{|l|}{ Control variables } \\
\hline $\begin{array}{l}\text { Related to } \\
\text { correctional } \\
\text { facility }\end{array}$ & N_INMAT & 65 & 538.65 & 646,47 & 386.89 & $0.0025^{* * *}$ & $\begin{array}{l}\text { Number of inmates held in } \\
\text { the correctional facility } \\
\text { (annual average) }\end{array}$ \\
\hline $\begin{array}{l}\text { Related to } \\
\text { correctional } \\
\text { facility }\end{array}$ & $A G E$ & 65 & 17.18 & 27.68 & 2.41 & $0.0002^{* * *}$ & $\begin{array}{l}\text { Number of years since the } \\
\text { correctional facility started } \\
\text { operating }\end{array}$ \\
\hline $\begin{array}{l}\text { Related to } \\
\text { correctional } \\
\text { facility }\end{array}$ & OVCROWD & 65 & 1.038 & 1.06 & 1.01 & $0.0795 *$ & $\begin{array}{l}\text { Overcrowding rate in the } \\
\text { prison. } 1 \text { means } 100 \% \text { of } \\
\text { the existing capacity }\end{array}$ \\
\hline $\begin{array}{l}\text { Related to } \\
\text { correctional } \\
\text { facility }\end{array}$ & LOCALIZ & 65 & 0.569 & - & - & - & $\begin{array}{l}\text { Dummy variable related to } \\
\text { facillity localization: } 1 \text {, if } \\
\text { in non-metropolitan areas; } \\
0 \text {, if located in expressive } \\
\text { urban center. }\end{array}$ \\
\hline $\begin{array}{l}\text { Related to } \\
\text { correctional } \\
\text { facility }\end{array}$ & CONVICT & 65 & 0.338 & - & - & - & $\begin{array}{l}\text { Dichotomic variable: } 1 \text {, if } \\
\text { prison holds individuals } \\
\text { awaiting trials; } 0 \text {, if prison } \\
\text { holds convicted inmates }\end{array}$ \\
\hline $\begin{array}{l}\text { Related to inmate } \\
\text { population }\end{array}$ & EASY_INM & 65 & 0.527 & 0.47 & 0.607 & $0.0637^{*}$ & $\begin{array}{l}\text { Number of prisoners of } \\
\text { "easy convivence" } \\
\text { according to psychological } \\
\text { evaluation }\end{array}$ \\
\hline $\begin{array}{l}\text { Related to inmate } \\
\text { population }\end{array}$ & INM_WORK & 65 & 0.468 & 0.465 & 0.473 & 0.118 & $\begin{array}{l}\text { Rate of prisoners who } \\
\text { work in the operational } \\
\text { activities of the prison. }\end{array}$ \\
\hline
\end{tabular}


Table 3: Results of security and order indicators

\begin{tabular}{|c|c|c|c|c|c|c|}
\hline & (1) & $\begin{array}{l}\text { ESCAPES } \\
\text { (2) }\end{array}$ & (3) & (4) & $\begin{array}{l}\text { DEATHS } \\
\text { (5) }\end{array}$ & (6) \\
\hline OUTSOURC & $\begin{array}{l}-3.327 * * * \\
(0.865)\end{array}$ & $\begin{array}{l}-2.076 * * * \\
(0.767)\end{array}$ & $\begin{array}{l}-1.874^{* *} \\
(0.802)\end{array}$ & $\begin{array}{l}-0.662 \\
(0.429)\end{array}$ & $\begin{array}{l}-0.844^{* *} \\
(0.387)\end{array}$ & $\begin{array}{l}-0.616^{*} \\
(0.367)\end{array}$ \\
\hline$A G E$ & $\begin{array}{l}-0.012 \\
(0.016)\end{array}$ & & $\begin{array}{l}0.0151 \\
(0.0134)\end{array}$ & $\begin{array}{l}0.002 \\
(0.008)\end{array}$ & & $\begin{array}{l}0.010^{*} \\
(0.006)\end{array}$ \\
\hline OVCROWD & $\begin{array}{l}-0.262 \\
(2.141)\end{array}$ & & $\begin{array}{l}-1.915 \\
(2.019)\end{array}$ & $\begin{array}{l}0.306 \\
(1.45)\end{array}$ & & $\begin{array}{l}0.735 \\
(1.280)\end{array}$ \\
\hline LOCALIZ & $\begin{array}{l}0.361 \\
(0.989)\end{array}$ & & $\begin{array}{l}0.452 \\
(0.672)\end{array}$ & $\begin{array}{l}-0.827 * \\
(0.462)\end{array}$ & & $\begin{array}{l}-0.243 \\
(0.378)\end{array}$ \\
\hline CONVICT & $\begin{array}{l}0.098 \\
(1.017)\end{array}$ & & $\begin{array}{l}-0.509 \\
(0.577)\end{array}$ & $\begin{array}{l}-0.626 \\
(0.455)\end{array}$ & & $\begin{array}{l}-0.78 * * * \\
(0.293)\end{array}$ \\
\hline$I N M \_W O R K$ & & $\begin{array}{l}0.384 \\
(1.103)\end{array}$ & $\begin{array}{l}0.557 \\
(1.167)\end{array}$ & & $\begin{array}{l}-1.424^{* *} \\
(0.699)\end{array}$ & $\begin{array}{l}-1.56^{* *} \\
(0.618)\end{array}$ \\
\hline EASY_INM & & $\begin{array}{l}-5.569 * * * \\
(1.262)\end{array}$ & $\begin{array}{l}-6.692^{* * *} \\
(1.671)\end{array}$ & & $\begin{array}{l}-0.431 \\
(0.730)\end{array}$ & $\begin{array}{l}-0.914 \\
(0.636)\end{array}$ \\
\hline Intercept & $\begin{array}{l}0.615 \\
(2.518)\end{array}$ & $\begin{array}{l}1.630 * * * \\
(0.451)\end{array}$ & $\begin{array}{l}3.60 * \\
(2.130)\end{array}$ & $\begin{array}{l}0.415 \\
(1.613) \\
\end{array}$ & $\begin{array}{l}0.998 * * \\
(0.401)\end{array}$ & $\begin{array}{l}0.615 \\
(1.454)\end{array}$ \\
\hline$N$ & 64 & 64 & 64 & 65 & 65 & 65 \\
\hline Wald $\chi^{2}$ & $15,22 * * *$ & $28.96 * * *$ & $27.90 * * *$ & 9.33* & $10.41^{* *}$ & $48.39 * * *$ \\
\hline
\end{tabular}

Table 4: Results of services provided to inmates indicators

\begin{tabular}{|c|c|c|c|c|c|c|c|c|}
\hline & \multicolumn{4}{|c|}{ MEDICAL ASSISTANCE } & \multicolumn{4}{|c|}{ LEGAL ASSISTANCE } \\
\hline & $(1)$ & $(2)$ & (3) & (4) & (5) & (6) & $(7)$ & $(8)$ \\
\hline OUTSOURC & $\begin{array}{l}1.526 * \\
(0.923)\end{array}$ & $\begin{array}{l}0.945 \\
(0.859)\end{array}$ & $\begin{array}{l}3.716^{* * *} \\
(0.528)\end{array}$ & $\begin{array}{l}1.473 \\
(1.395)\end{array}$ & $\begin{array}{l}-2.892 \\
(2.996)\end{array}$ & $\begin{array}{l}-2.143 \\
(2.655)\end{array}$ & $\begin{array}{l}0.4363 \\
(2.373)\end{array}$ & $\begin{array}{l}-3.099 \\
(1.927)\end{array}$ \\
\hline N_INMAT & $\begin{array}{l}-0.011^{* *} \\
(0.005)\end{array}$ & & $\begin{array}{l}-0.016^{* * *} \\
(0.003)\end{array}$ & $\begin{array}{l}-0.006 \\
(0.004)\end{array}$ & $\begin{array}{l}-0.032 * \\
(0.017)\end{array}$ & & $\begin{array}{l}-0.008 \\
(0.0137)\end{array}$ & $\begin{array}{l}-0.0042 \\
(0.006)\end{array}$ \\
\hline$A G E$ & $\begin{array}{l}0.231^{* *} \\
(0.093)\end{array}$ & & $\begin{array}{l}0.350 * * * \\
(0.0542)\end{array}$ & $\begin{array}{l}0.005 \\
(0.051)\end{array}$ & $\begin{array}{l}0.271 \\
(0.319)\end{array}$ & & $\begin{array}{l}0.109 \\
(0.244)\end{array}$ & $\begin{array}{l}-0.0077 \\
(0.070)\end{array}$ \\
\hline OVCROWD & $\begin{array}{l}7.095^{* *} \\
(2.915)\end{array}$ & & $\begin{array}{l}10.38 * * * \\
(2.269)\end{array}$ & $\begin{array}{l}10.25^{* *} \\
4.20\end{array}$ & $\begin{array}{l}37.40 * * * \\
(9.289)\end{array}$ & & $\begin{array}{l}23.70^{* *} \\
(10.20)\end{array}$ & $\begin{array}{l}16.18^{* * *} \\
(5.79)\end{array}$ \\
\hline LOCALIZ & $\begin{array}{l}-0.307 \\
(2.274)\end{array}$ & & $\begin{array}{l}0.133 \\
(0.811)\end{array}$ & $\begin{array}{l}-0.727 \\
(2.035)\end{array}$ & $\begin{array}{l}-7.240 \\
(8.312)\end{array}$ & & $\begin{array}{l}1.472 \\
(3.645)\end{array}$ & $\begin{array}{l}-1.01 \\
(2.816)\end{array}$ \\
\hline CONVICT & & & & $\begin{array}{l}0.050 \\
(2.545)\end{array}$ & & & & $\begin{array}{l}1.955 \\
(3.524)\end{array}$ \\
\hline INM_WORK & & $\begin{array}{l}3.51^{* *} \\
(1.48)\end{array}$ & $\begin{array}{l}2.743 * * \\
(1.354)\end{array}$ & $\begin{array}{l}2.317 \\
(2.928)\end{array}$ & & $\begin{array}{l}4.509 \\
(5.237)\end{array}$ & $\begin{array}{l}2.92 \\
(6.087)\end{array}$ & $\begin{array}{l}5.26 \\
(4.039)\end{array}$ \\
\hline EASY_INM & & $\begin{array}{l}-4.05 * * * \\
(1.425)\end{array}$ & $\begin{array}{l}-5.68 * * * \\
(0.95)\end{array}$ & $\begin{array}{l}-1.47 \\
(2.639)\end{array}$ & & $\begin{array}{l}2.185 \\
(4.508)\end{array}$ & $\begin{array}{l}0.724 \\
(4.272)\end{array}$ & $\begin{array}{l}2.20 \\
(3.642)\end{array}$ \\
\hline Intercept & $\begin{array}{l}0.181 \\
(3.573) \\
\end{array}$ & $\begin{array}{l}4.572 * * * \\
(1.172)\end{array}$ & $\begin{array}{l}-0.525 \\
(2.459) \\
\end{array}$ & $\begin{array}{l}-1.812 \\
(5.728) \\
\end{array}$ & $\begin{array}{l}-8.828 \\
(11.876) \\
\end{array}$ & $\begin{array}{l}4.672 \\
(3.104) \\
\end{array}$ & $\begin{array}{l}-16.496 \\
(11.055) \\
\end{array}$ & $\begin{array}{l}-8.461 \\
(7.90)\end{array}$ \\
\hline$N$ & 43 & 43 & 43 & 65 & 43 & 43 & 43 & 65 \\
\hline$R^{2}$ & 0.5349 & 0.2867 & 0,8230 & 0.2574 & 0.1577 & 0.088 & 0.2496 & 0.2564 \\
\hline Wald $\chi 2$ & $11.85^{* *}$ & $12.46^{* *}$ & $162.78 * * *$ & $12.37^{+}$ & $18.64 * * *$ & 1.58 & $11.64^{+}$ & $17.59 * *$ \\
\hline
\end{tabular}

Note: $* p<0.10 * * p<0.05 * * * p<0.01$. GLS Random-effect estimates; standard errors in parenthesis. 
Table 5: Comparative performance indicators in Bahia prisons

\begin{tabular}{|c|c|c|c|c|}
\hline \multirow{2}{*}{$\begin{array}{l}\text { Indicators } \\
\text { Administrative }\end{array}$} & \multicolumn{2}{|c|}{$\begin{array}{c}\text { Conjunto Penal de } \\
\text { Valença } \\
\text { (Privately-operated) } \\
\end{array}$} & \multicolumn{2}{|c|}{$\begin{array}{l}\text { Conjunto Penal de } \\
\text { Teixeira de Freitas } \\
\text { (Publicly-operated) } \\
\end{array}$} \\
\hline & 2003 & 2004 & 2003 & 2004 \\
\hline Facility capacity & 268 & 268 & 268 & 268 \\
\hline Inmates held & 227 & 251 & 258 & 246 \\
\hline Number of employees & 114 & 117 & 137 & 132 \\
\hline Number of employees absences & 4 & 4 & 10 & 15 \\
\hline Number of fired / laid-off employees & 9 & 6 & 0 & 2 \\
\hline $\begin{array}{l}\text { Correctional officer average monthly } \\
\text { salary (R\$ / month) }\end{array}$ & 645,45 & 683,75 & 981,00 & $1.176,00$ \\
\hline $\begin{array}{l}\text { Security and Order } \\
\text { Escapes attempts }\end{array}$ & 0 & 0 & 10 & 15 \\
\hline Escapes & 0 & 0 & 3 & 5 \\
\hline Assaults among inmates & 1 & 2 & 16 & 19 \\
\hline $\begin{array}{l}\text { Number of inmates released or sent to } \\
\text { probation / parole }\end{array}$ & 148 & 498 & 48 & 131 \\
\hline Dental assistance (appointments-year) & 500 & 614 & 587 & 620 \\
\hline Medical assistance (appointments year) & 2880 & 5316 & 250 & 430 \\
\hline Legal advisory (appointments year) & 3276 & 7488 & 258 & 246 \\
\hline \begin{tabular}{|l|}
$\begin{array}{l}\text { Psychological assistance (appointments } \\
\text { year) }\end{array}$ \\
\end{tabular} & 632 & 738 & 430 & 485 \\
\hline
\end{tabular}

